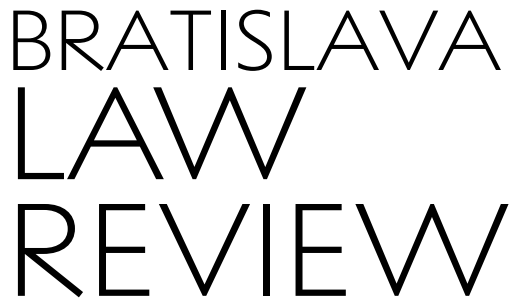

\title{
CONNECTING GENDER IDENTITY AND FREEDOM OF CONSCIENCE IN RECENT ROMANIAN CONSTITUTIONAL CASE-LAW / Mihail Stănescu-Sas
}

\author{
Mihail Stănescu-Sas \\ PhD Student \\ University of Bucharest \\ Faculty of Law \\ Kogălniceanu nr. 36-46 \\ București 050107, Romania; \\ as well as judge at Constanţa Court \\ of Appeal, \\ Strada Traian nr. 35C \\ Constanţa 900743, Romania. \\ stanescu-sas.mihail@drept.unibuc.ro \\ ORCID: 0000-0003-0037-4750 \\ This paper is the result of a research \\ conducted during the author's doctora \\ programme within the University of \\ Bucharest - Faculty of Law - Doctora \\ School of Law and has been presented \\ on 22 April 2021 at the online \\ international academic conference \\ "Bratislava Legal Forum 2021", held \\ under the auspices of the Alumni Club \\ of Comenius University in Bratislava \\ Faculty of Law
}

Submitted : 03 May 2021

Accepted: 09 June 2021

Published : 30 December 2021

\begin{abstract}
The Constitutional Court of Romania has recently ruled unconstitutional a new provision amending the Law regarding national education, meant to prohibit "any activity of disseminating the theory or opinion of gender identity, understood as the theory or opinion that gender is a concept different from biologic sex and that the two are not always the same". This provision was found in breach of several constitutional principles, including freedom of conscience and freedom of expression. This decision makes for a brief ingression into the legal nature of gender identity and that of freedom of conscience, allowing for the former to serve as a means to clarifying the scope of application of the latter. Since gender identity recognition is not a "world view", but a reflection of diversity which is integral to a plural, democratic society, the only way the said provision breached freedom of conscience involved its interior dimension: the freedom of thought of pupils and students. But it did not even involve an interference with the right to manifest a "conviction", as far as pupils, students and also teachers are concerned. Nonetheless, it breached their freedom of expression.
\end{abstract}

Key words: freedom of conscience; gender identity; freedom of expression; equality before the law; Constitution of Romania, Romanian law

Suggested citation:

Stănescu-Sas, M. (2021). Connecting Gender Identity and Freedom of Conscience in Recent Romanian Constitutional Case-Law. Bratislava Law Review, 5(2), 43-60. https://doi.org/10.46282/blr.2021.5.2.236

\section{INTRODUCTION}

\subsection{Factual Premise}

A recent decision of the Constitutional Court of Romania recognized a significant connection between gender identity and freedom of conscience. ${ }^{1}$ Seized by the President

\footnotetext{
${ }^{1}$ Romania, Constitutional Court of Romania, decision No. 907/16, December 2020, published in the Official Monitor of Romania, part I, No. 68/21, January 2021. Unless otherwise specified, further reference to Court's case-law reports to this particular decision.
} 
of Romania to perform a constitutionality check before promulgation, ${ }^{2}$ the Court, by a majority of 7 to 2 , ruled unconstitutional a provision of a new law adopted by Parliament, which, within the institutions of education, as well as on their entire premises, including out-of-school educational facilities, would have prohibited "any activity of disseminating the theory or opinion of gender identity, understood as the theory or opinion that gender is a concept different from biologic sex and that the two are not always the same."3

This provision, intended to be integrated into the Law No. 1/2011 regarding national education, ${ }^{4}$ was found in breach of several constitutional principles: freedom of conscience (article 29); equality before the law (article 16 paragraph 1) in relation to access to education (article 32) and to child and youth protection (article 49); academic autonomy (article 32 paragraph 6); freedom of expression and the prohibition of censorship (article 30 paragraphs 1 and 2); the rule of law and the principle of abiding by the Constitution and laws (article 1 paragraphs 3 and 5) and the priority of international provisions regarding fundamental human rights (article 20 paragraph 2).

All these grounds of unconstitutionality, following either the reasoning of the Court or a different perspective I envisage hereby, converge to a certain connection between gender identity and freedom of conscience: is the dissemination the concept of gender identity a manifestation of freedom of conscience? Because, if it is, then opposing it and disseminating the counter-concept of gender identity non-existence might be equally protected. The stake of sliding such a matter under the ambit of freedom of conscience may be to obtain a certain public privilege of credibility; but it may as well be a way to discredit it: since it is a matter of conscience, nobody is bound by it. This strategy may deliver fine results when it is applied to antidemocratic religious and non-religious claims, but may backfire into the democratic values, when they are lowered to the level of their contrary.

This contribution is intended to prefigure an equation between freedom of conscience and democratic values, where the latter don't get mixed up with their opposite under the scope of freedom of conscience. This fundamental freedom is not the battlefield between democracy and non-democracy, between equal human rights and their destruction. Freedom of conscience provides for the protection of manifestations of conscience outside the field of the political and of its corollary law, ${ }^{5}$ inside which only

\footnotetext{
${ }^{2}$ According to article 146 letter a) of the Constitution (republished in the Official Monitor of Romania, part I, No. 758/29, October 2003), the Constitutional Court may be seized to perform a constitutionality check of a law adopted by Parliament, before it is promulgated by the President of Romania (promulgation being necessary for its coming into force). The legal standing belongs to the President of Romania, to each of the Presidents of the two Chambers of Parliament, to the Government, to the High Court of Justice and Cassation, to the Ombudsperson and to a group of at least 50 deputies or 25 senators.

${ }^{3}$ Law regarding the amendment and addend of Law No. 1/2011 regarding national education - project No. L87/2020, adopted by the Senate, as decisional Chamber, https://www.senat.ro/legis/PDF/2020/20L087LP.PDF. Romanian parliamentary procedure provides for a bill to be submitted to one of the Chambers of Parliament: in principle, the first Chamber seized is the Senate, except for expressly provided matters, when the first Chamber seized is the Chamber of Deputies (article 75 paragraph 1 of the Constitution). In this case, the last solution applied, as the bill regarded the general organization of education [article 73 paragraph 3 letter $n$ ) of the Constitution]. After the bill is adopted or rejected by the first Chamber seized (in this case it was adopted), it is sent to the other Chamber (the Senate, in this case), which holds the attribute of being "decisional", meaning it will finally decide over the bill (article 75 paragraph 3 of the Constitution). The adopted law is sent to the President of Romania for promulgation. The President may demand the Parliament, only once, to reexamine the law. The President is obliged to promulgate the law adopted after re-examination (article 77 of the Constitution). The President may also seize the Constitutional Court, as described in the previous note. ${ }^{4}$ Published in the Official Monitor of Romania, part I, No. 18/10, January 2011.

5 "The premise and means by which the political power may put itself forward as a factor of social command are the creation and exercise of legal norms." (Safta, 2020, p. 5).
} 
the alternative protection of freedom of expression is to be sought. Freedom of conscience is way far from being a Trojan horse into democracy.

\subsection{Freedom of Conscience}

In Romanian constitutional law, freedom of conscience is an inclusive category. Provided by article 29 of the Constitution, it protects freedom of thought (formulated as "freedom of thought and opinion"), religious freedom (as "freedom of religious beliefs"), freedom of "convictions" (religious or non-religious), autonomy of religious organisations and the right of parents and tutors to perform, according to their own convictions, the education of minor children within their responsibility.

Thus, in my opinion, freedom of conscience incorporates the freedom of thought, that is the whole of the individual freedom over the forum internum, no matter the subject of thought, ${ }^{6}$ and the freedom to manifest religious and non-religious "convictions", which is only a part of thought, while the manifestations of the other part are protected by freedom of expression. So, freedom of conscience and freedom of expression govern the same indivisible power the individual holds over the forum internum; meanwhile, the protection of forum externum is partially shared and partially split: it is generally protected by freedom of expression (article 30 paragraph 1 textually providing for the freedom to express "thoughts, opinions and beliefs", the latter evoking the "religious beliefs" in article 29 paragraph 1); but forum externum is also especially protected by freedom of conscience, when it consists of "religious beliefs" and other equivalent "convictions".

This complicated architecture has led the Constitutional Court to combine the two fundamental freedoms, stating that "freedom of conscience implies, inevitably, the freedom of expression, which allows for the exteriorization, by any means, of thoughts, opinions, religious beliefs or spiritual creations of any kind." ${ }^{77}$ This statement is undoubtedly correct, but only when read from the proper angle. Freedom of conscience implies freedom of expression in two ways. First, they share the same freedom of thought/opinion, exercised in the forum internum. Second, all exterior manifestations of freedom of thought are protected by freedom of expression. But those exterior manifestations of "convictions" are also protected by freedom of conscience, whose level of protection may sometimes prove to be more effective, through either norms of accommodation, or conscientious objections.

In order to shape the scope of application of freedom of conscience, it is essential to define the "convictions", in the context of freedom of conscience. The European Court of Human Rights provides a classical definition, stating, with reference to article 2 of Protocol No. 1 to the Convention that "the word "convictions", taken on its own, is not synonymous with the words "opinions" and "ideas", such as are utilised in Article 10 (art. 10) of the Convention, which guarantees freedom of expression; it is more akin to the term "beliefs" (in the French text: "convictions") appearing in Article 9 (art. 9) - which guarantees freedom of thought, conscience and religion - and denotes views that attain a certain level

\footnotetext{
${ }^{6}$ This view is not unanimous. It has been argued that freedom of thought protects only "a form of thought about wide concern social phaenomena, having a direct connection to the exercise of state power, such as politics, religion, law, economy etc." (Ionescu, 2017, p. 391). However, I see thought as an indivisible matter, incompatible with any attempt of compartmentalisation, as the only way to value the absolute protection of forum internum. Fields of thought cannot be classified because nobody can properly understand the thought of another, not to say his or her own, as thought is only partially expressible. The only way to respect freedom of thought is to acknowledge its full integrity, as an indivisible purview where the individual is sovereign.

${ }^{7}$ Romania, Constitutional Court of Romania, decision No. 485/6, May 2008, published in the Official Monitor of Romania, part I, No. 431/9, June 2008
} 
of cogency, seriousness, cohesion and importance." 8 This definition is workable provided that it is interpreted in the light of the case-law excluding political manifestations, although religiously or philosophically motivated, from the scope of article 9 of the Convention. ${ }^{9}$

\subsection{Gender Identity}

As held by the provision found by the Court to be unconstitutional, gender identity doctrine states that "gender is a concept different from biologic sex and that the two are not always the same".

Philosophically speaking, gender identity houses a conflict between collective identity and individual identity, as sex is a collective identifier and gender is an individual one.

Collective identity resides upon an attribute or collection of attributes a community attaches to an individual member. Since basically all communities recognize the identifying value of biological sex, it is automatically attached to individuals. It is a determinism that communities use to identify their members and to assign them with precise roles corresponding to this biological feature.

Individual identity is, at least in part, the product of individual choice. Already subject to the determinism of biological sex, the individual may need an additional (though potentially challenging) concept in order to freely choose certain social roles and behaviour, no matter how traditionally assigned they are between the two biological sexes. Hence, the concept of gender is essentially challenging the absolute determinism of biological sex, as far as individual identity is concerned. In turn, those who deny the difference between the two concepts actually repudiate gender entirely; they argue that biological sex confers a collective identity that is unquestionable, immutable and nonderogative, so that, if "gender" exists, it is the same as biological sex.

Thus, the debate between the proponents of biological sex and those of gender is a fight between collectivism and individualism, over the territory of individual identity. The former embrace the prevalence of a collective identity (unilaterally and immutably recognized by the community), while the latter sustain, in relation to a certain part of the individual personality, the primacy of an individually chosen identity (based more or less on physical and/or psychological properties, but nevertheless freely assumed by the individual, in addition to biological sex).

In the contest between the two opposing doctrines, democratic values ensure the primacy of the individual identity over the collective, a solution in absence of which the concept of gender would be devoid of any significance. In this way, even though it is in the nature of any community to allocate collective identities, which actually build and maintain its identity as a group, these collective identities (attributes attached by the community to the individuals) are not unquestionable, immutable and non-derogative. The individual has a say in the matter of the social roles and behaviour he or she is choosing to undertake, which form the corollary of his or her identity. To this end, the individual uses an individual attribute - gender. Gender is an individual identity not because it is created in a unique fashion by the individual, as the concrete aspects of it may be shared with other people, but because it is freely and individually chosen, not collectively assigned.

\footnotetext{
${ }^{8}$ ECtHR, Campbell and Cosans v. United Kingdom, App. No. 7511/76 and 7743/76, 25 February 1982, § 36. ${ }^{9}$ ECtHR, Enver Aydemir v. Turkey, App. No. 26012/11, 07 June 2016, §§ 79 and 80; European Commission of Human Rights, Arrowsmith v. United Kingdom, App. No. 7050/75, report of 12 October 1978, § 75; European Commission of Human Rights, F.P. v. Germany, App. No. 19459/92, decision of 29 March 1993.
} 
This paper is not dealing with any concrete aspects of gender identity, among which some might be controversial or at least require extensive examination. It is not an endorsement of any particular opinion or aspect aiming to fit under the scope of gender identity. All reference to this concept relates to its mere existence as a fact of life, different from biological sex. It is this mere existence of gender identity that the examined provision, adopted by the Parliament and struck by the Constitutional Court, tended to prohibit entirely from being disseminated within the educational system.

\section{PUPILS' AND STUDENTS' FREEDOM OF CONSCIENCE}

\subsection{Constitutional Court's Assessment}

The Court noted in $\S 79$ of its decision that the educational system plays an essential role in the exercise of freedom of conscience, understood as "the possibility of the person to have and to publicly express his or her world view". In this regard, it quoted article 4 of Law No. 1/2011 regarding national education, according to which education aims to ensure "personal fulfilment and development", "social integration and active citizen participation within society", "forming a conception of life, based upon humanist and scientific values, national and universal culture and stimulation of intercultural dialogue", "education in the spirit of dignity, tolerance and respect for fundamental human rights and freedoms", "cultivation of sensitivity to human matters, to moral and civic values". The Court then stated that "[t]hese principles, which can be subsumed to freedom of conscience, are incompatible with the imposition by law of a "truncated" knowledge of reality. A view about life cannot be "prescribed" or imposed by the state through establishing certain ideas as absolute truths and forbidding, de plano, any step to find out other opinions/theories on the same subject, all the more so as these opinions/theories are promoted/sustained scientifically and legally, marking evolutions of society at a certain time."

It can be noticed that, even after having made an extensive presentation of the legal national and international context regarding gender identity ( $\S \S 51-76$ ) and concluding that the normative evolutions show that "gender identity/gender equality represent more than biological sex/biological differences, thus refuting gender stereotypes attached to the traditional approach of men and women's roles in society", the Court struggled to avoid stating its own substantial view related to gender identity, instead fitting it into the scope of freedom of conscience; the only vague approbation may be sustained by the expression "evolutions of society", which, semantically, suggests changes for the better.

Following this line of argument, in order to reach a conclusion of breach of freedom of thought, the Court stated that prohibiting any activity related to knowledge and debate within the educational system constrains pupils and students and also teachers to adopt and express, on educational premises, only the opinion recognized by the state, by law, that gender is identical with biological sex. This is contrary to freedom of conscience ( $\S 80)$, for the protection of which "the educational system is supposed to be open to ideas, values, opinions and to encourage their free expression and criticism." The state "has to support the formation of a world view, but not to impose it" (§ 81).

The Court also declared the analysed provision of the law to be in breach of article 1 paragraph 3 of the Constitution, according to which human dignity is a supreme value within the state, so that obstructing the knowledge and also the dissemination of "opinions regarding gender identity contrary to that imposed by the state, which can come into conflict with opinions, convictions and maybe with the gender identity a person 
perceives, is contrary to human dignity." According to the Court, "the wish of the state, through its authorities, to promote at a certain moment a conception about the notions of "sex" and "gender" must not transform into an act of imposition and punishment for the steps taken to know/make known the opinions about this theme" (§ 83).

\subsection{Indoctrination by Omission}

The innovative value of this decision is that it recognizes and illustrates a case of indoctrination by omission, amounting to a breach of freedom of thought. This conclusion is not set aside by the fact that indoctrination is this time ideological, so it does not involve what in terms of freedom of conscience is called "convictions", but only a political approach, because indoctrination breaches freedom of thought no matter the subject of thought. Since, within society, there are two opposing opinions regarding gender identity, forbidding to learn and teach about one of them, within the educational system, implicitly favours the other. Pupils and students are presented a distorted reality, where only one absolute truth appears to exist, while the contrary opinion is strategically absconded. Thus, their mind may develop in a fake environment, making them more difficult to acknowledge gender identity, when they eventually find it out later in life. The purpose of the constraint is obviously not the protection of children and young people, as the prohibition was meant to be absolute, no matter the age of the pupils or the pedagogic methods applied, but concealing gender identity matter in order to increase the odds for them to reject the concept when they grow up, as they were not taught about it in school.

Nonetheless, indoctrination by omission is not universally applicable. In the absence of an explicit provision of the law, teachers' omission to mention gender identity in class may be completely contingent and non-intentional. As the law does not provide that it has to be taught, gender identity may be approached differently from teacher to teacher, from class to class, from year to year, according to mere disposition. Seeing this as indoctrination by omission would be an exaggeration. Teachers miss providing certain information all the time and this fact, taken alone, does not prove that it was done so as to indoctrinate. In order to respect the right to education, which is to be understood in view to the formation of members of a democratic society, the state is supposed to manifest a certain care for creating and maintaining a pedagogic framework allowing for proper civic education, including that of democratic values, such as equality under its different aspects, but should not be expected to pursue a teacher for failing to deliver one particular information. So, contingent omission does not amount to indoctrination.

But then, the purpose of constraining people to adopt the idea favoured by the state, which they are presented to be the absolute truth - although a competing idea challenges it, can be followed not just by adopting a law, but by a quasi-universal practice. That is, even if there is no legal constraint one way or another, teachers may still not bother to mention anything about gender identity, since there is no law compelling them to do so. Then, teachers may change their view and teach only about gender identity, concealing or actively criticising the now reputedly anachronistic view that sex and gender are the same.

If indoctrination is possible to be produced by an omission prescribed by the law, then it should also be seen as such when it is the result of a quasi-universal practice, even in the absence of a law, as the practice would be just as unconstitutional as the law. ${ }^{10}$ This means that the state has a positive obligation to create and maintain a legal

\footnotetext{
${ }^{10}$ Indeed, repressing an unconstitutional practice, which is not related to constitutional procedures, exceeds the jurisdiction of the Constitutional Court, therefore it belongs to regular courts.
} 
framework allowing people to act in order to stop or to change an unconstitutional practice, such as indoctrination by omission. Eventually, either directly by law or indirectly by court judgments, the state would have to prescribe the proper conduct in order to exclude indoctrination.

The guiding principle in this regard is pluralism, which, according to article 8 paragraph 1 of the Constitution, "is a condition and a guarantee of constitutional democracy". "Pluralism manifests in all ambits of life: social, political, labour-union, organic or institutional. Pluralism means, then, spirit of tolerance, mutual respect and pacifism" (Deaconu, 2017, p. 37). It is because of pluralism, meaning the social value that is attached to diversity, that the respect for freedom of conscience and for the other human rights is a reality or at least a reasonable expectation.

In this line of thought, the democratically prescribed conduct is one, which overtly favours diversity: there should be a proper way for teachers to inform pupils and students about the concept of gender identity, because, whether one accepts it or not, it is a conception certain people share without truly harming the others. Favouring diversity, the Court indirectly favours the gender identity upholders, as their adversaries deny pluralism by maintaining that gender and biological sex are the same.

However, the Court insists in keeping the position opposing gender identity within the frame of pluralism, even when it is directed against pluralism. This exercise of ostensible "neutrality" is confusing. After all, the debate about gender identity is just about another opinion or it is more than that? Is it concerning a non-religious conviction, maybe competing certain religious beliefs? Is it a matter of human rights, of equality, of respect for the private life?

These questions lead right back to the start. What are education and gender identity about?

\subsection{Education is a Limitation of the Freedom of Thought}

Leaving aside the "neutrality" exercise, meant to emphasize that education involves knowing and debating several opinions, accepting diversity and sometimes the conflict of ideas, the reasoning of the Court seems to miss the point that education is, in itself, a limitation of the freedom of thought. It is widely stated that freedom of thought is absolute (Sudre, 2019, p. 786), but education is nonetheless an exception.

Education, either performed by parents and tutors or by schools, is meant to shape and to influence thought. Any piece of knowledge does that: adding a fact to a previous reasoning, due to finding out relevant information, may lead to a different conclusion than before. As one might think that, in this way, he or she has gained something for his or her conscience, another may perceive it as a loss. Learning one thing may discredit what was learned before. Not learning it prevents from knowing the truth. It so happens that, as the discussed case proves, education influences thought either by action or by omission. And so, it is in itself a limitation of the freedom of thought.

Performed institutionally, education changes people and is doing it by systematically following the aims the Court referred to in $\S 79$ of its decision, as provided by article 4 of the Law regarding national education; among them, "education in the spirit of dignity, tolerance and respect for fundamental human rights and freedoms."

Freedom of thought allows people to conceive life and the world in complete contradiction with the spirit of universal human dignity, tolerance and human rights. Everybody is entitled to disregard certain people or groups of people, no matter who constructed the stereotypes this attitude feeds upon. Nevertheless, pluralism does not spread that far as to provide for its own destruction, that is for an "impartial" education 
about the values of tolerance and those of persecution, about human rights and the disregard of them, about equality before the law, aside with collective privileges and absolute collective identities.

As a common way of reproducing its values, any state uses the education system to shape the thought of its citizens. A democratic state does that by teaching them democratic values, including tolerance, human rights, human dignity, equality before the law. It does that in spite of certain citizens not acquiescing to these values. As the Court notes in the same $\S 79$, the state aims to empower citizens to enjoy their rights and freedoms, beginning with their freedom of thought. This, by definition, requires rejecting the challenging doctrines of individual disempowerment, as it happens to be that which denies the mere existence of gender identity.

Therefore, the principle that "the protection of freedom of thought implies the prohibition of any kind of indoctrination, of imposing an ideology" (Selejan-Guţan, 2020, p. 256) must not be taken to the extreme. Democratic values, as ideological in nature as they are, since they do not derive from revelation nor from science, are to be taught in schools. Pluralism excludes its own denial. Tolerance excludes intolerance. ${ }^{11}$ Equal respect for human rights excludes preventing people to learn that explicit provisions of the law guarantee it.

As education is by itself a limitation of freedom of thought, but not to the extent of indoctrination, a line has to be drawn between the two notions. If a certain fact is unsure, controversial or subject to religious or philosophical belief, the school is to be neutral. This is the case of scientific uncertainty, of religious revelation and dogma or of opinions related to the political game. But if a fact is reasonably certain, there is no justification to hide behind neutrality, which simply does not apply to such cases. There is no point in telling children things that are utterly untrue or to cast doubt over things which are certain. Neutrality is not there to equalize truth and untruth. Neutrality is not a means to prevent the reproduction of a culture based upon the state guaranteed exercise of equal human rights. Neutrality is a means to realize all that. Hence, state neutrality does not preclude, but instead requires, that young people are educated not to discriminate against others, including on grounds of gender identity. In this way, they will be able to fully enjoy their rights and freedoms while respecting those of others. Neutrality and non-discrimination are inter-related, as discrimination exhibits prejudice, and state indifference to discrimination, due to the refusal to recognize an identity factor such as gender, would prove all but neutrality. So, neutrality can never serve as an argument for indifference to discrimination.

\section{4 "A World View"}

In Romanian constitutional law, freedom of conscience is regularly defined as the right to adopt, to have, to change, to manifest or to abandon "a world view". ${ }^{12}$ The term conspicuously reflects the concern to encapsulate religion and non-confessional doctrines, as well as the lack of any of them. Whereas the expression holds the merit of being integrative, it is not to be taken literally.

\footnotetext{
${ }^{11}$ It was shown that "tolerance should not be tolerated unless the intolerant response to intolerance will reduce significantly the total level of tolerance in society as a whole or will cause undesirable harm to desirable values or interests." (Nehushtan, 2018, p. 38). These exceptions exceed the matter here discussed, as the analysed provision of the law did not respond to such objectives and gender identity teaching is not reasonably expected to produce or increase intolerance within society, nor any breach to democratic values.

12 See Muraru (2019, p. 250). The notion evokes the German concept "Weltanschauung", meaning "a general world view" (Blackburn, 2016, p. 504).
} 
The notion appears to be extremely wide, although, in my opinion, it excludes two important domains that have a lot to do with "a world view": science and ideology. Science involves many times a diversity of opinions, but in some matters it is certain. In common algebra, $1+1=2$. Manifesting a different belief does not express "a world view", but a generally recognized scientifical failure. Then, scientifical controversies are to be carried on scientifical grounds. A scientifical truth or possibility may be accepted or not in terms of either conscience or ideology, but this kind of acceptance or denial is external to science itself. Ideology, understood as any doctrine regarding the organization and functioning of society and public power, encompasses certain values and technical means necessary to this end. Law reflects both democratic values and many bits of different comprehensive ideologies selected through the democratic process. Law, and human rights in particular, image themselves "a world view". And yet, being ideological in its core, law, as well as the ideologies it puts in place, is not a manifestation of freedom of conscience. One does not have to obey the law only when subscribing to its deeply perceived moral meaning. Also, one does not have the right to obtain a change within the law only to put it in line with a "world view". Abiding by the law, breaking the law, criticising the law, militating for amending the law, even when they originate from the principles and norms of a religious or an equivalent non-confessional doctrine, or make up no more than a political ideology, are not manifestations of freedom of conscience. ${ }^{13}$ They are the manifestations of an ideology, be it attached or not to a religious or to a non-religious doctrine.

Not seeing this difference between religious and non-religious doctrines on the one hand and science and ideology on the other may lead, as it so happened, to the error of taking gender identity for a matter of freedom of conscience.

In fact, gender identity is partly scientifical and partly ideological. It is scientifical to the extent it involves the cognition of the objective fact that there are people who sincerely think that their or other people's gender is different than their biological sex. This is a matter central to the individual identity of those who state it with regard to their own persons, their sense of themselves, which significantly influences their lives. It is ideological insofar as it is socially valued as an expression of diversity and a fulfilment of pluralism, a way of recognizing equal human dignity and equal human rights. Gender identity recognition falls within the principles of democracy, understood as a social system designed for the protection of human rights. From democratic ideology, gender identity passed into law, benefiting from a non-negligible legal recognition. Essentially, gender identity recognition expresses principles of equality, justice and human dignity. On the other part, it does not show any democratic downfall; it does not harm or threaten other people's rights and freedoms, it challenges only intolerance, which anyway falls outside the law (article 29 paragraph 2 of the Constitution).

To conclude, endorsing gender identity recognition is not, in my opinion, a manifestation of freedom of conscience, since it only involves a partly scientific and partly ideological opinion; therefore, it is protected under the common regime of freedom of expression. Endorsing a contrary opinion follows the same path. However, the two

\footnotetext{
${ }^{13} \mathrm{As}$ I have argued elsewhere, the conscientious objection is a typical manifestation of freedom of conscience. Even if the law does not expressly provide for it (meaning there is no norm of accommodation), so that, to the unaccustomed eye, it may appear as a breach of law, the conscientious objection actually lies within the law (Stănescu-Sas, 2020, p. 48). Whether the objection is admissible or not depends on the proportionality of the legally prescribed obligation, considered as a limitation of the freedom of conscience, with the legitimate aim pursued, in as far as this limitation is necessary in a democratic society. For more see ECtHR, Bayatyan v. Armenia [GC], App. No. 23459/03, 7 July 2011, § 112.
} 
opinions are not equal, since one is tolerant, therefore democratic, and the other is not. Teaching that gender exists as a concept different from that of sex (a fact which is expressly provided by national law) ${ }^{14}$ is no more than civic education, to which the young citizens of a democratic state are entitled to, under their right to education. In the end, parents' and tutors' convictions may not deny them the realization of this human right.

\section{TEACHERS' FREEDOM OF CONSCIENCE}

\subsection{A Breach of Freedom of Expression}

I remind that the Court found the analysed provision in violation of freedom of conscience, as far as both freedom of thought and freedom to express an opinion endorsing gender identity are concerned. I supported only the first conclusion, in the part that regards pupils' and students' freedom of thought, as the new provision prescribed an indoctrination by omission. However, in my opinion, it did not interfere with their freedom to manifest their convictions, as well as their parents' convictions, since gender identity recognition is a matter of basic civic education, in line with the values of a plural, democratic society.

The Court also found a breach of teachers' freedom of conscience, the criticised provision forcing them to adopt and to express only the opinion recognized and promoted by the state, which, in the field of education, rejects gender identity recognition (although it promotes it, by law, anywhere else). I don't see how the teachers' freedom of thought is touched by this provision, but this issue is marginal. More important is whether their freedom of conscience is involved.

In this point, the legal reasoning meets the ambit of freedom of expression. The Court stated that "prohibiting access to the knowledge of an opinion and to its expression only because it doesn't concord with that of the state over an issue - hereby gender identity - appears from this perspective as a manifest violation of freedom of conscience in a democratic society, impossible to subsume to the limits provided" exhaustively by article 30 paragraphs 6 and 7 of the Constitution ${ }^{15}$ ( $\S 94$ ). According to these provisions, "[f]reedom of expression may not affect dignity, honour, person's private life and the right to one's own image" and the following actions are prohibited by law: "defamation of country and nation, incitement to war of aggression, to national, racial, class or religious hatred, to discrimination, to territorial separationism or to public violence, as well as obscene manifestations, contrary to morals." Additionally, the Court found the criticised provision to be in contradiction with the principle of academic freedom, as provided by article 123 of Law No. 1/2011 regarding national education, and also in violation of the constitutional principle of academic autonomy, provided by article 32 paragraph 6 of the Constitution (§§ 95 and 90). The Court concluded that "the prohibition of the free expression of the theory of gender obviously brings about the prohibition of any research initiative in this field, the criticised provision imposing, independent of any free debate or research, a dogmatic, truncated education, restraining for the free expression of teachers and the beneficiaries of the act of education, ignoring their right to opinion" (§ 90).

\footnotetext{
14 Infra, note 17. Also, article 2 paragraph 5 of Government Ordinance No. 137/2000 regarding the prevention and punishment of all forms of discrimination, republished in the Official Monitor of Romania, part I, No. 166/7, March 2014, defines harassment making explicit reference to gender. Article 4 paragraph 2 letter I) of Government Ordinance No. 43/2003 regarding the achievement and administrative change of name by individuals, published in the Official Monitor of Romania, part I, No. 68/2, February 2003, provides for the right to change one's first name following a sex change operation.

${ }^{15}$ Romania, Constitutional Court of Romania, decision No. 650/25, October 2018, published in the Official Monitor of Romania, part I, No. 97/7, February 2019, § 584.
} 
It is unquestionable that the analysed provision breaches the freedom of expression of pupils and students as well as that of teachers. It is an interference with this fundamental freedom that is not justified by any legitimate aim, provided by article 30 paragraphs 6 and 7 of the Constitution or by article 10 paragraph 2 of the European Convention of Human Rights.

Still, the interpretation of the criticised provision in the sense that gender identity recognition does not concord with "the opinion" of the state is not to be taken lightly. The same goes for the Court's notice in $\S 83$ that the said provision expresses "the wish of the state, through its authorities, to promote at a certain moment a conception about the notions of "sex" and "gender"." What is retainable here is that the Court qualified the examined provision as the expression of an opinion of the state or of the wish of the state; as if two contrary opinions capered through society and the state adopted one of them; it cannot force people to adopt it, but can nonetheless hold it. In my view, this equation does not hold.

If there were actually two contrary opinions, and they had political meaning, the solution that is adopted by law necessarily reflects the "opinion" of the state. Nobody would reasonably question the prerogative of the state to enforce its "opinion" upon society and apply the said legal solution. During this time, political debate whether the other solution is better or worse remains open and protected by freedom of expression. But the "opinion" of the state is always that which stems from its current legislation. There cannot be an "opinion" of the state outside its legislation, because, under the rule of law, the state cannot express "opinions" but by its law.

In the case hereby, the only expression of the "opinion" allegedly directed against the concept of gender identity came from a provision found to be unconstitutional, which therefore never entered into force; so, there is not and there cannot actually be any state "opinion" denying the said concept, as it is not even possible to express it within a valid, constitutional legislation.

\subsection{Gender Identity and Equality before the Law}

Keeping equality before the law in the field of the right to education, the Court secured the former solely on the grounds that the criticised provision discriminated against those who preferred to study the gender identity theory (§ 85), but failed to state on the issue which is the most striking: prohibiting, by law, the dissemination of the simple existence of the concept of gender identity is in itself a breach of the principles of equality before the law and of non-discrimination. Here, the matter is not whether God created man or the latter just evolved from monkey, which are two conflicting theories that equally reject each other. This is about the social recognition of individual identity, faced with denial. On the one hand, somebody states his or her own identity; on the other hand, somebody denies somebody else's identity, while keeping his or her own safe. Gender identity recognition is a facet of equality, so that everybody can have a say about his or her own identity, while bluntly denying somebody else's identity is no more than a facet of discrimination. This ideological conflict is not to be dealt with the serenity which otherwise attends opposing opinions which do not involve denying the contenders' conception of themselves.

Therefore, if the criticised provision were phrased the other way round - that gender identity is to be mentioned during some class in schools, I believe it would have been constitutional, as it responded the already quoted aim of education provided by article 4 of the Law No. 1/2011, to be "in the spirit of dignity, tolerance and respect for fundamental human rights and freedoms", the latter being a supreme value of the state 
(article 1 paragraph 3 of the Constitution). Teaching about gender equality may require a little more skill than teaching against racism, antisemitism or homophobia, may need a certain pedagogic contribution as to which is the proper age for introducing it to young people and which are the proper educational means to do that, but it is not any different in essence; it is still about teaching tolerance, equal respect and non-discrimination.

The Court did not follow this line of thinking. It found the criticised provision to be "almost anachronistic", because it bluntly restricted access to education concerning "a notion which, by the multitude of legal, sociologic, psychologic meanings, may entail a variety of study and research areas" and which is "long time present within the social and legal landscape" (§ 86). Here, the Court recalled that the authors of the bill intended to forbid only "proselytism, meaning the acts of convincing young people to embrace an idea/theory". In that case, "maybe there could have been made considerations in terms of the conditions to restrain rights and freedoms". But "[h]iding/denying/repressing an opinion does not prompt its disappearance and neither can "protect" the individual from the allegedly detrimental effects the state would wish to prevent, as far as children and youth education is concerned" (§ 87).

To put it simply, the Court recognizes the right of pupils and students to be educated in relation to gender identity, since this is a serious concept, which deserves to be studied. The Court fails to point out that gender equality, all the more so reflected in legislation, is an aspect of equality before the law which itself is a principle to be taught as such. The evocation of the initial bill is, in this context, troubling. The initiators intended to prohibit "proselytism on grounds of gender", ${ }^{16}$ as defined by article 4 letter $\mathrm{d}^{3}$ ) of Law No. 202/2002 regarding the equality of chances and treatment between women and men ${ }^{17}$ - version initially adopted by the Chamber first seized. ${ }^{18}$ So, actually, teachers were meant to be prevented from endorsing, in the exercise of their job, an explicit provision of the law, which defines a facet of the constitutional principle of equality. And still, the Constitutional Court found that, if this version had been adopted, maybe it would have performed a check upon the legitimacy to limit the exercise of rights and freedoms meaning that a certain limitation of the right to education might be taken into consideration, as some pupils and students would sustain a limitation into their alleged right to avoid education in the letter and spirit of equality before the law. Nevertheless, envisaging such a right is rather dubitable, since it falls outside the scope of education in a democratic society, which involves the recognition and valorisation of equality and of diversity in all its forms.

In the end of the decision, the Court stated that "Romanian legislation prohibits discrimination on grounds of sexual orientation, provides legislative solutions for situations

\footnotetext{
16 This is an interesting case of reverse legal rhetoric. Instead of prohibiting discrimination on grounds of gender, as the law already provides, the initiators intended to prohibit "proselytism on grounds of gender", using the same language, but reversing the sense. The term "proselytism" was obviously out of place, since the debate was not about adopting a doctrine, which is totally optional, but about the shape and size of equality before the law. The words "on grounds of gender" ["pe baza criteriului de gen" - in original], attached to "proselytism", instead of "discrimination", induce the idea that the prohibition of discrimination was only the manifestation of a creed, that is not to be exercised by dissenters, but only by "proselytes". An independent analyst might however notice that the blunter wording of the prohibition eventually adopted by the Senate, replacing the insidious wording of the initial version, was more likely to fail in front of the Constitutional Court, as the reasoning of the its decision illustrates.

${ }^{17}$ Republished in the Official Monitor of Romania, part I, No. 326/5, June 2013. According to article 4 letter $d^{3}$ ), gender is "the entirety of roles, behaviours, features and activities that society sees fit for women and, respectively, for men."

${ }^{18}$ Law regarding the amendment and addend of Law No. 1/2011 regarding national education - project No. PLX617/2019, adopted by the Chamber of Deputies, as Chamber first seized, available at: https://www.senat.ro/legis/PDF/2020/20L087FC.PDF (accessed on 15.11.2021).
} 
of sex change, the distinction between "sex" and "gender" [being] connected, by article 20 of the Constitution, to the international legal framework." In this context, the criticised provision "equates with the passing of legal solutions that mutually exclude, making a confuse and contradictory normative framework" (§ 99). This "conceptual contradiction of the legislator [...] cannot be accepted because it generates a lack of coherence, clarity and predictability of the legal norm, putting the subjects of the law in the position of not being able to adapt their conduct." In this sense, the Court found a breach with the rule of law and the principle of abiding by the Constitution and laws (article 1 paragraphs 3 and 5 of the Constitution), as well as with the primacy of international provisions regarding fundamental human rights (article 20 paragraph 2 of the Constitution) (§ 100).

Beyond this, it should not be absconded that the conspicuous contradiction between the criticised provision - literally a denial of education related to the concept of "gender equality" - and the principle of equality, sustained by the whole legal framework providing for non-discrimination on grounds of gender, which the Court carefully reviewed in $\S \S 51-76$ of its decision, is due to the breach of the principle of equality itself. The Court acknowledges that gender identity is provided by the national law and by international instruments regarding human rights, which hold primacy over national legal provisions, according to article 20 paragraph 2 of the Constitution, but allows for the interpretation that, in the same time, gender identity is established anywhere else but in the Constitution of Romania. Were the national and international legislation recognizing gender identity ever to be repealed, so that the contradiction just faded away, then it would seem unclear whether the Constitution opposed.

The principle of equality before the law, provided by article 16 paragraph 1 of the Constitution of Romania, in the context of the principle of pluralism, provided by article 8 paragraph 1, is nevertheless not hollow. It encompasses, beyond its wording, a whole democratic culture of human rights, in the shadow of the supreme values provided by article 1 paragraph 3, among which are human dignity, citizens' rights and freedoms, free development of human personality and justice. Whether recognizing and teaching gender identity is meant to realize or, on the contrary, to violate any of these supreme values is not actually a genuine legal quarrel.

\subsection{Manifestations of Conscience in a Democratic Society}

In order to conclude, one more clarification is needed. It may appear that, since gender identity is already recognized by national and international legislation, the prohibition of its dissemination would run against the conscience of typical members of a democratic society. That is, since gender identity recognition reflects democratic values, namely those of pluralism and equal respect for individual human rights, its exterior manifestation might be taken for an act of conscience. I believe it is not. It is still a manifestation of an ideology and therefore it has nothing to do with freedom of conscience.

Calling democratic values ideologic is not to be taken by democratic consciences as offending, nor by the antidemocratic as encouraging. Both perceptions would be utterly wrong. As already stated, democratic values are ideologic since they are neither products of revelation, nor of science. The fact that they are incorporated into law and law forms a science, does not take away their ideologic nature, as the roots of law are always ideologic. Law is about enforcing a conception of justice that nature fails to produce itself. It is not the law that made up social values, but the other way round. There was a social need for law and a respected legal order, based upon already existing values, even before the law existed. Equality before the law stands within the law only because 
members of democratic societies value it in the form they do. Human rights, justice and human dignity spring from religious and philosophical doctrines whose proponents have passed the frontiers of their closed circles and engaged into a free political society. Values which are religious or philosophical in their origin join other values and so become political; or, to say the word again, ideological.

In order to turn into law, a religious or philosophical principle enters the political market, where it assumes an ideologic nature, as only is this form it may be negotiated to become a part of the social contract and thus be adopted by the whole society. The whole society, at least when it is democratic, never professes a certain religion or equivalent philosophic doctrine; people profess many of those. Although it rejects the sectarian value of a principle that has been presented, it may still adopt it in the light of its ideologic form. An entire society, as well as the state it is organized in, does not profess a religion or an equivalent philosophical doctrine. It only professes a contractual ideology; the fact that the latter may be a synthesis of religious and non-religious doctrines is irrelevant as far as its nature is concerned.

It is not the social value of an idea (whether it is democratically "good" or "bad") that makes it an act of conscience. It is rather its nature. No matter if it springs from a religious or an equivalent philosophical doctrine, when the idea turns political, its nature is no more than ideologic. For instance, the commandment to help the needy may be religious or philosophical, but when it turns into principles of a state operated social security system, it becomes ideologic. Passed into law, the obligation to contribute to a public budget that serves also to this end is no longer a matter of free choice; people have to pay whether they believe in its purpose or not. When religious or equivalent philosophical commandments pass onto the political stage to attempt being translated into laws, they are no more than other political claims. They are protected by freedom of expression, but they are not manifestations of freedom of conscience.

I do not expect opposition to the idea that teachers are prohibited from expressing, within the exercise of their profession, ideas which are of an undisputed antidemocratic nature, like supporting the activity of suicide bombers who make political claims in order to establish a religious state, of those who commit violent attacks against crowds or individuals as a response to religious frustration or of those who work to establish a dictatorship. People's conscience can produce all that. It is their freedom of thought. It is the way they may "view the world". But nevertheless, in order to protect both public order and the rights and freedoms of other people, teachers are prevented to manifest such thoughts in class, even if they sincerely and intensively hold them. There is no conscientious objection admissible is this regard because all these are only political (therefore ideological) claims, situated outside the scope of freedom of conscience. It is only the exercise of freedom of expression that is limited here.

As the apology of antidemocratic ideas exceeds the ambit of freedom of conscience, so does the apology of democratic values, such as gender equality. There is no reason to force the scope of application of freedom of conscience, stuffing the endorsement of democratic values inside it. These are well protected under the freedom of expression and the other rights and freedoms related to political action, such as the right to association and the freedom of assembly. But, most of all, their nature is ideologic and has nothing to do with the manifestations of conscience. To state otherwise is to jam both democratic and antidemocratic manifestations into the scope of freedom of conscience and finally to erase any difference between that and freedom of expression, so that freedom of conscience is devoid of its substance. 


\section{CONCLUSION}

I have argued that prohibiting the dissemination of an idea within education institutions is a case of breach of pupils' and students' freedom of thought, since the forum internum is indivisible, in the sense of article 29 paragraph 1 of the Constitution. At the interior level, there is no distinction between thoughts, according to their nature, so they (or, more exactly, the thought itself) are evenly protected.

However, at the exterior level, that of manifestations, a clear distinction must be drawn between religious or philosophical acts of conscience on the one hand and ideological manifestations on the other hand. While both are protected by freedom of expression, only the former are protected by freedom of conscience. Holding democratic values, as well as antidemocratic views, is protected by freedom of thought (which is a part of freedom of conscience), but their exterior manifestation exceeds the scope of this fundamental freedom. This is due to their ideologic nature, as they underlie or at least aim to shape the way society and public power are organized and function.

In the exercise of an ideology, since freedom of conscience is not applicable, there is no conscientious objection. This is true either if the stance taken is the expression of democratic values or it is the expression of contrary views.

The concept of gender identity serves well as a means to explain this distinction. It is connected to freedom of conscience as far as its interior dimension (freedom of thought) is concerned, as prohibiting the dissemination of this concept within the educational system amounts to indoctrination by omission. But this is only because thought is indivisible. This prohibition has however nothing to do with any manifestation of freedom of conscience. Instead, it breaches the freedom of expression, the right to education, academic autonomy, human dignity, as well as equality before the law.

A democratic state cannot be "neutral" as far as both democratic values and their contrary are concerned. It openly supports democratic values ${ }^{19}$ and is expected to refute views, which are contrary. It promotes and enforces equal individual rights and freedoms and, to this purpose, it sanctions discrimination. This does not mean that the state is to recognize any alleged individual or collective identity. But gender identity recognition and its corollary, gender equality, are already recognized and protected by the law. As the Court stated in $\S 57$, "the Constitution contains no distinction as to identify the belonging to the feminine (or masculine) sex turning to biological or some other kind of criteria. Article 16 correlated with article 4 of the fundamental Law enshrines formal equality, regardless of sex." This is a way of saying that the constitutional concept of "sex" might actually be read also as "gender". Even if the Court's reasoning did not eventually follow this reading of the Constitution when it found violations of several of its articles, as previously shown, but instead accepted to integrate both gender identity recognition and its denial in the sphere of a pluralism of opinions, I believe that gender equality can be found within the Constitution, either if "sex" is read as "gender", as the Court seems to imply, or if the general wording of the principle of equality before the law in article 16 paragraph 1 of the Constitution incorporates gender as any of the relevant facts of life that shall not be a ground for discrimination.

\footnotetext{
19 In this regard, it was shown that "the terms "Constitution" and "constitutionalism" refer to the enforcement of certain conducts, according to a certain selection of values intrinsic to a human community" (Deaconu, 2020, p. 111).
} 


\section{BIBLIOGRAPHY:}

Blackburn S. (2016). The Oxford Dictionary of Philosophy. Third edition. Oxford: Oxford University Press. 531 pages. ISBN 978-0-19-873530-4.

Deaconu Ş. (2020). Drept constituţional. Fourth edition. Bucharest: C.H. Beck. 266 pages. ISBN 978-606-18-1016-1.

Deaconu Ş. (2017). Instituţii politice. Third edition. Bucharest: C.H. Beck. 315 pages. ISBN 978-606-18-0720-8.

Ionescu C. (2017). Commentary of Article 29. In: Ionescu, C. and C. A. Dumitrescu (eds.), Constituţia României. Comentarii şi explicaţii. Bucharest: C.H. Beck, pp. 383-401. ISBN 978-606-18-0681-2.

Muraru I. (2019). Commentary of Article 29. In: Muraru I. and E.-S. Tănăsescu (eds.), Constituţia României. Comentariu pe articole. Second edition. Bucharest: C.H. Beck, pp. 249-256. ISBN 978-606-18-0847-2.

Nehushtan Y. (2018). Intolerant Religion in a Tolerant-Liberal Democracy. Oxford and Portland, Oregon: Hart Publishing. 203 pages. ISBN 978-1-50992-008-2 and 9781-84946-605-9.

Safta M. (2020). Drept constituţional şi instituţii politice. Vol. II. Instituţii politice. Third edition. Bucharest: Hamangiu. 384 pages. ISBN 978-606-27-0675-3.

Selejan-Guţan B. (2020). Drept constituţional şi instituţii politice. Volume 1. Fourth edition. Bucharest: Hamangiu. 306 pages. ISBN 978-606-27-1643-1.

Stănescu-Sas M. (2020). Impactul măsurilor de prevenţie sanitară dispune în context pandemic asupra manifestării libertăţii conştiinţei. In: Dimitriu O. (ed.), Probleme şi soluţii legale privind criza COVID-19. Bucharest: C.H. Beck, pp. 43-67. ISBN 978606-18-1000-0.

Sudre F. et al. (2019). Droit européen et international des droits de l'Homme. $14^{\text {th }}$ edition. Paris: Presses Universitaires de France. 946 pages. ISBN 978-2-13-080791-9.

Constitution of Romania, republished in the Official Monitor of Romania, part I, No. 758/29, October 2003.

ECtHR, Bayatyan v. Armenia [GC], App. No. 23459/03, 7 July 2011

ECtHR, Campbell and Cosans v. United Kingdom, App. No. 7511/76 and 7743/76, 25 February 1982

ECtHR, Enver Aydemir v. Turkey, App. No. 26012/11, 07 June 2016

European Commission of Human Rights, Arrowsmith v. United Kingdom, App. No. 7050/75, report of 12 October 1978

European Commission of Human Rights, F.P. v. Germany, App. No. 19459/92, decision of 29 March 1993

Government Ordinance No. 43/2003 regarding the achievement and administrative name change by individuals, published in the Official Monitor of Romania, part I, No. 68/2, February 2003.

Government Ordinance No. 137/2000 regarding the prevention and punishment of all forms of discrimination, republished in the Official Monitor of Romania, part I, No. 166/7, March 2014.

Law No. 1/2011 regarding national education, published in the Official Monitor of Romania, part I, No. 18/10, January 2011.

Law No. 202/2002 regarding the equality of chances and treatment between women and men, republished in the Official Monitor of Romania, part I, No. 326/5, June 2013.

Law regarding the amendment and addend of Law No. 1/2011 regarding national education - project No. PLX617/2019, adopted by the Chamber of Deputies, as Chamber first seized, available at 
https://www.senat.ro/legis/PDF/2020/20L087FC.PDF (accessed on 15.11.2021).

Law regarding the amendment and addend of Law No. 1/2011 regarding national education - project No. L87/2020, adopted by the Senate, as decisional Chamber, available at: https://www.senat.ro/legis/PDF/2020/20L087LP.PDF (accessed on 15.11.2021).

Romania, Constitutional Court of Romania, decision No. 907/16, December 2020, published in the Official Monitor of Romania, part I, No. 68/21, January 2021. Romania, Constitutional Court of Romania, decision No. 650/25, October 2018, published in the Official Monitor of Romania, part I, No. 97/7, February 2019.

Romania, Constitutional Court of Romania, decision No. 485/6, May 2008, published in the Official Monitor of Romania, part I, No. 431/9, June 2008. 
